\title{
Profissionalização e Cidadania: Visão de Mundo nas Escolas Técnicas Industriais*
}

\section{Pesquisadores: Margot Bertoluci Ott, Vera Regina Pires Moraes c Fábio de Lima Beek \\ Instituição: Universidade Federal do Rio Grande do Sul (UFRGS) \\ Fonte Financiadora: Instituto Nacional de Estudos e Pesquisas \\ Educacionais (INEP)/UFRGS}

O presente trabalho representa uma continuação do estudo da problemática das Escolas Técnicas Industriais (ETIs), que vem se desenvolvendo no País. Sua importância diz respeito às discussões que possa vir a promover sôbre a questão curricular das escolas de $2^{\circ}$ grau, enfocadas na perspectiva das escolas técnicas.

Esta pesquisa objetivou inventariar e discutir a questão curricular em cinco escolas técnicas industriais do Rio Grande do Sul c de Santa Catarina, tendo como referência, para a análise, as categorias profissionalização, cidadania c visão de mundo.

Os pressupostos teóricos e metodológicos da pesquisa parti- cipante conscientizadora foram utilizados como base orientadora. Atendendo às características desse tipo de pesquisa, o grupo de trabalho, constituído por professores representantes das escolas c pelos pesquisadores/coordenadores, discutiu e elaborou coletivamente todo o programa da investigação.

Primeiramente, o grupo estudou textos que analisam criticamente a problemática da educação técnica no Brasil, procurando relacionar seu conteúdo com a realidade das diferentes escolas.

Paralelamente, foi construído um questionário-base, tendo como referência as categorias já mencionadas. A partir deste questionário, foram elaborados coleti-

\footnotetext{
*Rcsumo da pesquisa Estudo das linhas curriculares das escolas técnicas industriais.
} 
vãmente os instrumentos a serem respondidos pelos diferentes segmentos integrantes da pesquisa. Participaram como respondentes 102 professores (envolvendo docentes de formação geral c especial), 99 alunos, 86 pais de alunos, 35 egressos e 38 funcionários. Foi também elaborado o Questionário Institucional, que visou à coleta de dados sôbre a escola como um todo. Este instrumento foi respondido pela equipe da direção de cada escola envolvida na pesquisa.

Da totalidade das respostas obtidas, derivaram subcategorias (grupos de conceitos c afirmações) que expressavam a compreensão do respondente a respeito das categorias analisadas. Essas subcategorias articuladas entre si, buscando um sentido de globalidade, contribuem para evidenciar a visão de mundo dos respondentes na sua interação com a instituição escolar.

O conjunto de dados foi analisado, buscando-se nexos c articulações intra e entre profissionalização, cidadania $c$ visão de mundo, tal como se apresentam nas escolas estudadas $\mathrm{c} \mathrm{cm}$ suas relações com a sociedade como um todo.
$\mathrm{Na}$ categoria profissionalização foram identificadas as subcategorias: qualificação técnica, integração escola/indústria, desenvolvimento psicossocial/humanização c relação indústria/ambiente. $\mathrm{Na}$ categoria cidadania foram encontradas as subcategorias: consciência, democracia, farsa/alienação, envolvimento/atuação política, mediação, lazer/humanismo c fatalismo/restrição. Na categoria visão de inundo emergiram as subcategorias: qualificação técnica, consciência, integração/competição e tecnologia/humanidade.

Salientaram-se, ao longo da análise, duas subcategorias: a de "qualificação técnica", numa perspectiva de aplicabilidade, $\mathrm{c}$ a de "consciência", enquanto consciência crítica, evidenciando parte da dinâmica que sustenta $c$ tece o real cm suas contradições.

A primeira subcategoria destacada trata da qualificação técnica proporcionada pela escola, do relacionamento das disciplinas com a realidade, da preparação para 0 trabalho e da tecnologia aprendida na escola e utilizada na empresa. Tal subcategoria se reveste de um caráter eminentemente pragmático 
e imediatista. Qualificação é entendida como instrumentalização, como aquisição de conhecimentos e habilidades na conquista de um lugar no mundo da produção. Esta qualificação é vista acima de tudo como decorrente da integração da escola com a empresa, de aulas práticas, estágios e simulações. Todavia, mesmo esta visão simplista de qualificação, que não envolve o domínio dos princípios científicos, fica, na prática, prejudicada pelas precariedades da escola. Evidenciam-se, entre as precariedades dessa instituções, seu estado de sucateamento, defasagem tecnológica, distanciamento da realidade e deficiências de recursos materiais. A pesquisa mostrou, também, que as instituições escolares tendem a reduzir o saber à instrumentalização e que, mesmo assim, em alguns casos, terminam por ensinar mais do que o aproveitado pela empresa.

$\mathrm{Na}$ vida da escola a idéia do concreto é reduzida ao manipulável, privado de seu significado de trama de relações. Assim, a "prática" vai perdendo seu sentido de praxis (relação entre o princípio e a ação), tornando-se mero fazer.

Essa visão forjada pelas forças da sociedade, e não só pela escola, é, em parte, responsável pela desqualificação que a falta do domínio dos princípios de conhecimento introduz, empobrecendo a possibilidade de reflexão, condição sine qua non para o trabalho qualificado. Submetida a essa situação, à distorção do significado da prática, à falta de reflexão, o próprio aluno fica confundido; desvaloriza a teoria e é impelido, pelas práticas sociais, a desejar as aprendizagens de utilização imediata.

A pesquisa aponta para a predominância do ensino com vistas à mera aplicação, constituindose em indicador de que os alunos das escolas técnicas são preparados para os cargos de execução e só, eventualmente, para os de administração da produção.

Consciência foi a segunda subcategoria destacada neste trabalho, e a mais referida por todos os segmentos respondentes na categoria cidadania. Esta subcategoria representa o saber e o refletir sobre a concretude da realidade do homem e da sociedade. Envolve, também, compromisso com a dinâmica da sociedade em direção a 
padrões de vida mais igualitários, incluindo as dimensões individual e coletiva.

A dimensão do coletivo apresenta-se em dois níveis de abrangência: um referido à classe trabalhadora e ao povo brasileiro como um todo e o outro a grupos profissionais específicos. Nas colocações dos participantes da pesquisa, $\mathrm{o}$ individual e o coletivo se mesclam. $\mathrm{O}$ desejo de atingir outros patamares individuais de bem-estar aparecem conjuntamente com as questões de ordem coletiva, sem contudo atingir uma relação de unidade.

Esse processo da consciência tem a ver, possivelmente, com a amplitude e a complexidade de seu objeto de reflexão. Isto sugere uma nítida relação entre o conteúdo da pré-ocupação da consciência e seu desenvolvimento. Entretanto, tal processo parece não decorrer diretamente do currículo formal, uma vez que este, na maioria das vezes, é desvinculado das grandes questões de nossa cultura, de nossa sociedade. O que há, todavia, no ambiente escolar que faz com que aí a dimensão da consciência e da cidadania encontre um espaço privilegiado para o seu desenvolvimento? Seria o encontro de gerações? Seria a escola, enquanto lugar consagrado à discussão, o terreno fértil para o desenvolvimento da consciência? Ou seria a emergência desta consciência a resultante do encontro das subjetividades que captam, nas diferentes esferas, as contradições da sociedade?

Isto nos leva a afirmar que apesar de todas as precariedades, da ausência quase total do tratamento das questões favorecedoras do desenvolvimento da consciência crítica no currículo formal, a escola é um espaço importante e indispensável à formação da consciência.

E, pois, de se considerar a força decisiva do currículo oculto, do currículo não previsto, e seu interjogo com o currículo formal. $\mathrm{O}$ currículo formal, ainda que seja apenas uma das variáveis da educação, é um fator potencial e decisivo neste processo.

A direção desta influência para a transformação pode, em certa medida, estar submetida ao poder da escola - professores, pais, alunos e funcionários, enquanto coletivo consciente - , ao incluir, 
no currículo formal, propostas consistentes capazes de quebrar tabus, promover autonomia intelectual, discutir, selecionar e produzir conhecimento, bem como avaliar os propósitos, interesses e necessidades dos diferentes grupos que compõem a sociedade.

Deve-se observar que o currículo é uma proposta de educação que implica a leitura do real, dizendo respeito à escola como um todo, sem subestimar a força isolada das disciplinas que o integram, pois é neste âmbito que os princípios fundamentais do conhecimento devem ser construídos e examinados.
Um novo currículo só pode começar a se delinear a partir da discussão e reflexão entre os próprios educadores e alunos, enquanto sujeitos participantes dos processos societários.

Esta pesquisa evidenciou que o auxílio dos agentes externos, quando associados aos representantes das escolas, pode ter algum impacto efetivo sobre os currículos, com vistas à qualificação técnica e à cidadania, quando os educadores e as próprias escolas estão comprometidos na análise de suas circunstâncias e com disposição para alterá-las. 